University of Rhode Island

DigitalCommons@URI

The Rhode Island Current Conditions Index

Economics

7-2004

\title{
Rhode Island Current Conditions Index - July 2004
}

Leonard Lardaro

University of Rhode Island, lardaro@uri.edu

Follow this and additional works at: https://digitalcommons.uri.edu/ricci

Part of the Econometrics Commons

Terms of Use

All rights reserved under copyright.

\section{Recommended Citation}

Lardaro, Leonard, "Rhode Island Current Conditions Index -- July 2004" (2004). The Rhode Island Current Conditions Index. Paper 138.

https://digitalcommons.uri.edu/ricci/138

This Article is brought to you for free and open access by the Economics at DigitalCommons@URI. It has been accepted for inclusion in The Rhode Island Current Conditions Index by an authorized administrator of DigitalCommons@URI.For more information, please contact digitalcommons-group@uri.edu. 


\section{Current Conditions I ndex \\ LEONARD LARDARO URI}

Also available online: http:/ / members.cox.net/ lardaro/ current.htm

Volume X, Number 10

July 2004

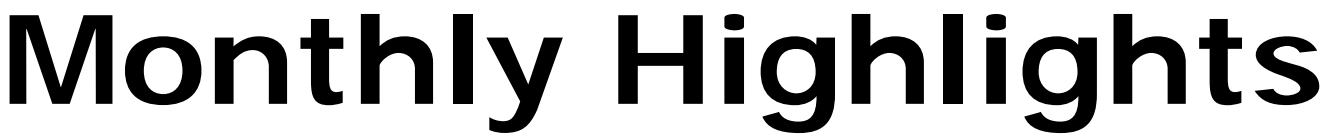

There is good news and bad news for July. First, the good news. The Current Conditions Index for July rose to 58, back into the expansion range, after June's below-neutral value of 42. Seven of the $\mathrm{CCl}$ 's indicators showed improvement, with three turning in very strong performances. Now for the bad news: the $\mathrm{CCl}$ failed to exceed its year-earlier value for the second consecutive month. Expect this trend to continue through the rest of this year, as the upsurge at the end of 2003 will not likely be repeated. More moderate growth is in our future. At least the "soft patch" of J une has ended.

Rhode Island's payroll employment increase this year has finally begun to catch up to the national rise after lagging well behind through May. Unfortunately, our state's Unemployment Rate has now matched or exceeded the national rate for the last four months, following a long period with below-national-average rates. Perhaps more troubling is the joint behavior of our Labor Force and Unemployment Rate: Rhode Island 's Labor Force fell by 0.6 percent in July (compared to July 2003), while our Unemployment Rate rose from 5.3 percent to 5.7 percent. Not a happy combination! Ironically, the strongest performance by any $\mathrm{CCl}$ indicator in July concerned long-term unemployment: the number of Benefit Exhaustions fell by an amazing 23

\begin{tabular}{|c|c|}
\hline \multirow{2}{*}{\multicolumn{2}{|c|}{\begin{tabular}{cc}
\multicolumn{2}{c}{ CCI Indicators - \% Change } \\
Government Employment & 0.2
\end{tabular}}} \\
\hline & 0.2 \\
\hline US Consumer Sentiment & 6.5 \\
\hline Single-Unit Permits & 1.1 \\
\hline Retail Sales & 3.0 \\
\hline Help Wanted Advertising & -5.9 \\
\hline Priv. Serv-Prod Employment & 1.1 \\
\hline Man-Hours Manufacturing & -0.8 \\
\hline Manufacturing Wage & 1.7 \\
\hline Labor Force & -0.6 \\
\hline Benefit Exhaustions & $-23.0 \mathbf{Y}$ \\
\hline New Claims & 1.4 \\
\hline $\begin{array}{l}\text { Unemployment Rate } \\
\qquad Y=I \text { mproved } V_{a}\end{array}$ & 7.5 \\
\hline
\end{tabular}

percent compared to last July, its fourth double-digit improvement in a row. But, while long-term unemployment continues to improve, the number of layoffs, as measured by New Claims, continued to worsen slightly, rising by 1.4 percent in July.

Private Service-Producing Employment continued to experience more rapid growth, as July's growth rate of 1.1 percent was an improvement over the rates of the past two months. Help Wanted Advertising fell by 5.9 percent in July, reflecting ongoing weakness in the demand for labor. In spite of ongoing budget difficulties, Government Employment continued its upward trend, rising by 0.2 percent.

The uneven pace of new home construction continued in July. Single-Unit Permits barely rose (by 1.1 percent), but this follows a 13 percent rise in June. The good news is that the number of Permits stayed above the 2,000 level at an annual rate once again. Retail Sales grew by 3 percent in July, more than erasing its decline last month, and remaining above its twelve-month average. US Consumer Sentiment rose again, by 6.5 percent in July, compared to the same month last year.

Rhode Island's manufacturing sector performance in July was mixed once again, as the decline in Manufacturing Manhours accelerated to a 0.8 percent rate, consistent with rates of decline over the past six months, but far better than the declines experienced during the July-October period in 2003. Rhode Island's Manufacturing Wage grew by 1.7 percent, a continuation of the recent uptrend in wage growth rates, moving our Manufacturing Wage to $\$ 13.11$.

We now enter a "slippery" period, with a host of uncertainties whose resolution will ultimately determine the pace of economic activity here for the remainder of this year. As I noted last month, it will be difficult for us to beat comparable ("comps") CCl values from the second half of last year. What Rhode Island needs most right now is a viable "engine" of job growth so that we aren't once again left behind when pace of national economic activity re-accelerates.

\section{Current Conditions I ndex}

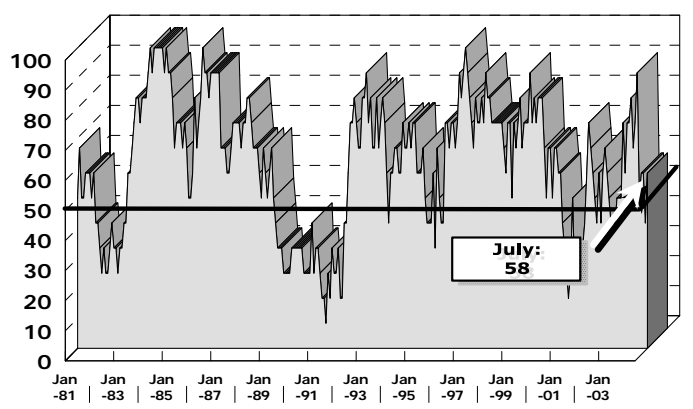

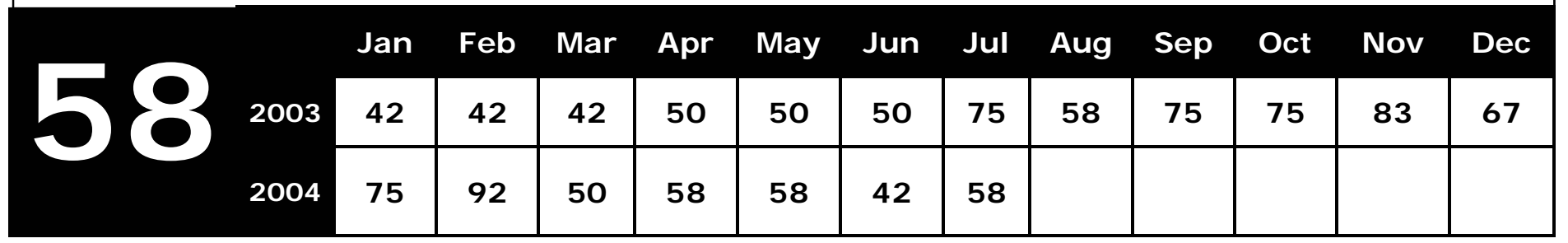

